\title{
Introduction to the Simon Fraser - University of Calgary Special Issue
}

\author{
Dana Cramera, Ben Schollb \\ a: York \& Ryerson Joint Graduate Program in Communication \& Culture, Ryerson/X \\ University \\ b: School of Communication, Simon Fraser University
}

With this year's graduate student conferences hosted separately at the University of Calgary and Simon Fraser University, our goal was to encourage discussion and debate around the topic of crisis. The COVID-19 pandemic has been at the forefront of public attention; even forcing our respective conferences into the disembodied safety of virtual space. However, it is important to remember that COVID19 is not the only crisis faced in recent years; the overdose crisis, crisis of the corporatization of universities, economic crisis, crisis of truth and misinformation, and the looming environmental threat of the Anthropocene, have been with us and will continue to be grappled with into the foreseeable future.

Crises echo through the past to the present, such as those experienced by our Indigenous communities. They re-emerge, still to be grappled with and struggled against. As individuals and researchers, we may assume any number of these crises are out of scope or outside our area of expertise. We often fail to consider them. However, crises defy temporality and spatiality as easily as disciplinary borders; both squeezing and stretching, accelerating, and suspending notions of the like. The contributors of this special issue consider an array of crises as they collide with diverse fields and disciplines, encouraging us to reflect on how they intersect our own. Ultimately, we aspire to trouble the notion of crises themselves. Questioning our understanding and reapplying it where we had not previously considered. In these general 'times of crisis,' what counts as such? How is it communicated and miscommunicated? What are the effects on resilience, recovery, and possibility? Where can we seize opportunity following a crisis?

The Chinese symbol for crisis is composed of two parts: opportunity and danger. Where the Simon Fraser University conference focused on resilience in a crisis, the University of Calgary conference expanded on potentials of opportunity. As invited editors to this special edition, we viewed contributors, not as tackling separate entities of the term 'crisis,' but instead, as a framework to building back 
stronger, seizing an opportunity, and practicing resiliency as we maneuver through this danger to a better future. As Zhang and Li (2018) have argued, it is in a cocreation of both sustainable and resilient development which can lead to assurances of overcoming and withholding a community's vulnerabilities, or their potential crises. This development may use standards setting as an opportunity to ensure resiliency (Thompson, 1954), encouraging democratic participation for an equal seat at the table, and taking the lessons learned during a crisis to apply to a better future (Brundtland, 1987).

In the field of communication, we are oftentimes stretched to an incohesive front based on the competing discourses of the canons of our field (Carey, 1997, 2009; Peters, 1999). The study of communications then is not a discipline, but a field of fields, perhaps a crisis of definition in our own knowledge community. In these competing views we see the beauty of this interdisciplinary and transdisciplinary research, as reflected in how graduate students across Canada thrive in their specializations. Emerging as a new group of scholars who, as the world was faced by crises all around, produced these articles in the pages which follow for this special edition; we as the invited editors see the ways in which graduate students practice resiliency in their work, seizing opportunities, and overcoming the crises which surround.

危机

Crisis. 


\section{References}

Brundtland, G. H. (1987). The world commission on environment and development: Our common future (United Nations General Assembly document A/42/427). United Nations.

https://sustainabledevelopment.un.org/content/documents/5987our-commonfuture.pdf

Carey, J. (1997). Communications and economics. In E. S. Munson \& C. A. Warren (Eds.), James Carey: A critical reader (pp. 60-75). University of Minnesota Press.

Carey, J. (2009). Communication as culture: Essays on media and society (Revised Edition). Routledge. https://ebookcentral-proquest-

com.ezproxy.lib.ryerson.ca/lib/ryerson/reader.action?docID=356343\&ppg=5

Peters, J. D. (1999). Speaking into the air: A history of the idea of communication. University of Chicago Press.

Thompson, G. V. (1954). Intercompany technical standardization in the early American automobile industry. The Journal of Economic History, 14(1), 1-20.

Zhang, X., \& Li, H. (2018). Urban resilience and urban sustainability: What we know and what do not know? Cities, 72, 141-148.

https://doi.org/10.1016/j.cities.2017.08.009 